\title{
EMBRYOGENIC CALLI INDUCTION FROM NUCELLAR TISSUE OF CITRUS CULTIVARS
} \author{
Garcia Borges Demétrio ${ }^{3,6}$; Beatriz Madalena Januzzi Mendes ${ }^{4,6}$ \\ ${ }^{1}$ Graduate Student. Depto. de Produção Vegetal - ESALQ/USP. \\ ${ }^{2}$ Depto. de Produção Vegetal - ESALQ/USP, C.P. 9 - CEP: 13418-900 - Piracicaba, SP. \\ ${ }^{3}$ Depto. de Ciências Exatas - ESALQ/USP. \\ ${ }^{4}$ Laboratório de Biotecnologia Vegetal - CENA/USP, C.P. 96 - CEP: 13400-970 - Piracicaba, SP. \\ ${ }^{5}$ Bolsista da FAPESP. \\ ${ }^{6}$ Bolsista do CNPq. \\ *e-mail: famourao@carpa.ciagri.usp.br
}

Fernanda Januzzi Mendes-da-Glóriaa,5; Francisco de Assis Alves Mourão Filhoº, ${ }^{2,6 *}$ Clarice

ABSTRACT: Nucellar tissues of seven Citrus varieties were introduced onto three growth media to produce embryogenic callus. The media tested were: EME [MT, modified, with the addition of malt extract $\left(500 \mathrm{mg} \cdot \mathrm{L}^{-1}\right)$ ]; 1/2-EME [half concentration of MT macronutrients + half concentration of BH3 macronutrients $+500 \mathrm{mg} \cdot \mathrm{L}^{-1}$ malt extract $+1.55 \mathrm{~g} \cdot \mathrm{L}^{-1}$ of glutamine]; and EBA [EME + $0.44 \mu \mathrm{M} 6-$ benzyladenine + $0.04 \mu \mathrm{M}$ 2,4 D]. Soft friable calli were obtained from 'Cravo' and 'Ponkan' mandarins (Citrus reticulata, Blanco), 'Murcott' tangor (Citrus reticulata Blanco x Citrus sinensis L. Osbeck), 'Serra d'água' and 'Valencia' sweet oranges (Citrus sinensis, L. Osbeck) 120 days after callus induction. 'Natal' and 'Pera' sweet oranges (Citrus sinensis, L. Osbeck) produced hard non-friable calli in this period. EME and 1/2-EME media had the best results for 'Cravo' mandarin, 'Ponkan' mandarin and 'Serra d'água' sweet orange, whereas EBA was the best media composition to induce soft friable calli on 'Murcott' tangor and 'Valencia' sweet orange. Friable callus cultures of 'Cravo' and 'Ponkan' mandarins, and 'Murcott' tangor yielded high quality protoplasts after isolation.

Abbreviations: a.c. - activated charcoal; BA - 6-benzyladenine; IAA - indole-acetic acid; 2,4-D - 2,4diclorophenoxyacetic acid; MT - Murashige \& Tucker basal medium.

Key words: biotechnology, tissue culture, cultivar improvement, growth regulator, protoplast

\section{INDUÇÃO DE CALOS EMBRIOGÊNICOS A PARTIR DE NUCELOS DE VARIEDADES DE CITRUS}

RESUMO: Nucelos de sete variedades de Citrus foram introduzidos em três meios de cultura para produção de calos embriogênicos. Os meios de cultura testados foram: EME [MT, modificado pela adição de extrato de malte (500 mg. $\left.\mathrm{L}^{-1}\right)$ ]; 1/2-EME [1/2 concentração de macronutrientes no meio MT + $1 / 2$ concentração de macronutrientes no meio $\mathrm{BH} 3+500 \mathrm{mg} \cdot \mathrm{L}^{-1}$ extrato de malte $+1,55 \mathrm{~g} \cdot \mathrm{L}^{-1}$ de glutamina]; e EBA [EME + 0,44 $\mu$ M 6-benziladenina + 0,04 $\mu \mathrm{M}$ 2,4 D]. Calos friáveis foram obtidos nas variedades tangerinas 'Cravo' e 'Ponkan' (Citrus reticulata, Blanco), tangor 'Murcote' (Citrus reticulata Blanco $x$ Citrus sinensis L. Osbeck), laranja 'Valencia' (Citrus sinensis L. Osbeck) e lima 'Serra d'água' (Citrus sinensis L. Osbeck) 120 dias após a instalação do ensaio. As laranjas 'Natal' e 'Pera' (Citrus sinensis L. Osbeck) produziram calos duros de crescimento lento neste período. Os meios EME e 1/2-EME mostraram os melhores resultados para as tangerinas 'Cravo' e 'Ponkan' e lima 'Serra d'água', enquanto que EBA foi o melhor meio de cultura para indução de calos friáveis de tangor 'Murcote' e laranja 'Valencia'. Calos friáveis das variedades, tangerinas 'Cravo' e 'Pokan' e tangor 'Murcote' foram subcultivados e apresentaram bom rendimento e qualidade de protoplastos após isolamento.

Palavras-chave: biotecnologia, cultura de tecido, melhoramento, regulador de crescimento, protoplasto

\section{INTRODUCTION}

Brazil leads Citrus world production (FAO, 1998), but, in spite of this position, the Brazilian varieties still lack fruit quality and high yields. Other factors such as disease and pest problems require the development of new Citrus varieties. Conventional Citrus breeding has been carried out, but not with much success for the release of new scion and rootstocks varieties (Grosser \& Gmitter Jr., 1990). 
Although there is a great diversity in the genus, the majority of new important Citrus varieties, originated as bud sport mutations from existing cultivars. The lack of good results through conventional Citrus breeding can be explained by various aspects of the biology of the genus Citrus and its relatives, including high heterozygozity, pollen and ovule sterility, sexual incompatibility, nucellar polyembryony and juvenility (Grosser \& Gmitter Jr., 1990).

Somatic hybridization through protoplast fusion allows the hybridization of sexually incompatible genera and species, which is often difficult or not possible by conventional breeding (Grosser \& Gmitter Jr., 1990; Grosser et al., 1996). Protoplast fusion can also be applied to Citrus scion improvement by producing tetraploid breeding parents to be used in $4 \mathrm{X} \times 2 \mathrm{X}$ crosses to develop new triploid seedless cultivars (Mourão Filho et al., 1996). Protoplasts can be isolated from different kinds of tissues, including leaf mesophyll, embryogenic callus, embryogenic suspension cultures and non-embryogenic callus (Grosser \& Gmitter Jr., 1990).

The objective of this research was to produce new embryogenic callus lines to be used as alternative sources for protoplast isolation. These protoplasts could then be combined with other Citrus species in protoplast fusion experiments for somatic hybrid production.

\section{MATERIAL AND METHODS}

Nucellar tissue of the following Citrus cultivars were cultured for embryogenic callus induction: 'Cravo' mandarin (Citrus reticulata, Blanco), 'Murcott' tangor (Citrus reticulata, Blanco $x$ Citrus sinensis L. Osbeck), 'Pera' sweet orange (Citrus sinensis L. Osbeck), 'Ponkan' mandarin (Citrus reticulata, Blanco), 'Natal' sweet orange (Citrus sinensis L. Osbeck), 'Serra d'água' sweet orange (Citrus sinensis L. Osbeck), and 'Valencia' sweet orange (Citrus sinensis L. Osbeck). Fruits from these cultivars were harvested from the germplasm collection at the "Centro de Citricultura Sylvio Moreira", in Cordeirópolis, SP, Brazil. 'Cravo' mandarin is a very early maturing cultivar and produces medium-large fruits, flattened in shape with loosely adhering rind, moderately to excessively seedy. 'Murcott' tangor is grown widely in Florida and Brazil. Trees are vigorous, bushy in shape with willowy leaves. Fruits are of medium size, slightly flattened at the base and apex, juicy and seedy (Saunt, 1990). 'Serra d'água' is an acidless sweet orange cultivar, mostly grown in Brazil. 'Pera' and 'Natal' sweet oranges are also very important cultivars in Brazil. The first is mid season variety. Fruits are slightly oval in shape, with a smooth thin rind. 'Natal' sweet orange resembles 'Valencia' sweet orange in most tree and fruit characteristics, and both are late maturing cultivars (Saunt, 1990).

Seeds in the initial stage of development (six months after fertilization) were excised from fruits and surface sterilized in $1.5 \%$ sodium hypochloride solution, for 15 minutes, and washed in sterilized distilled deionized water. The nucellus tissue was then extracted from the seeds with forceps and scalpel, under aseptic conditions and cultured onto three different media. Ten nucelli were introduced per Petri dish and 5 dishes per culture medium, in a total of 50 nucella per treatment and 150 nucella per Citrus cultivar. The culture media tested were: EME [Murashige \& Tucker, modified (Murashige \& Tucker, 1969), with the addition of malt extract $\left(500 \mathrm{mg}^{-\mathrm{L}^{-1}}\right)$ ] (Grosser \& Gmitter Jr., 1990); 1/2-EME [half concentration of MT macronutrients + half concentration of $\mathrm{BH} 3$ macronutrients $+500 \mathrm{mg} \cdot \mathrm{L}^{-1}$ malt extract $+1.55 \mathrm{~g} . \mathrm{L}^{-1}$ glutamine] (Grosser \& Gmitter Jr., 1990); and EBA [EME + $0.44 \mu \mathrm{M} 6-$ benzilaminopurine (BA) $0.04 \mu \mathrm{M}$ 2,4 D] (Gmitter Jr. et al., 1992).

Explants were cultured in disposable Petri dishes $(100 \times 15 \mathrm{~mm})$, sealed with plastic film, and maintained in the dark at $27^{\circ} \mathrm{C}$. Initial calli were transferred to new media without any growth regulators (EME) approximately every four weeks.

Qualitative and quantitative evaluations were conducted 120 days after culture. The best growing calli were selected in an effort to establish long-term callus lines. These selections were then subcultured on EME medium, with or without activated charcoal (500 $\mathrm{mg}^{-\mathrm{L}^{-1}}$ ), for protoplast isolation, followed by an evaluation of protoplast yield. The general protoplast isolation protocol was adapted from Grosser \& Gmitter Jr. (1990), and included approximately $500 \mathrm{mg}$ of fresh cultured cells $+2.0 \mathrm{ml} 0.7 \mathrm{M} \mathrm{BH} 3$ protoplast culture medium $+2.0 \mathrm{ml}$ enzyme solution (Grosser \& Gmitter Jr., 1990).

\section{RESULTS AND DISCUSSION}

Qualitative evaluations were conducted 120 days after culture, and calli were classified into three categories, based on their quality and vigor, as follows: slow-growing, hard callus; slow- 
growing, soft callus; and fast-growing, soft callus. Best results were obtained with 'Cravo' mandarin and 'Murcott' tangor, that produced fast-growing, friable calli on 1/2-EME and EBA media (Figure 1A). However, the same cultivars produced slowgrowing, friable calli on EME medium (Figure 1B). Slow-growing, friable calli of 'Valencia' sweet orange was produced on 1/2-EME and EBA media. 'Pera' sweet orange produced hard calli (Figure 1C) on EME and EBA media. No callus induction of this cultivar was observed on 1/2EME medium. 'Natal' sweet orange produced hard calli on all media tested. 'Serra d'água' sweet orange produced some slow-growing friable calli on EME and 1/2-EME, and hard calli
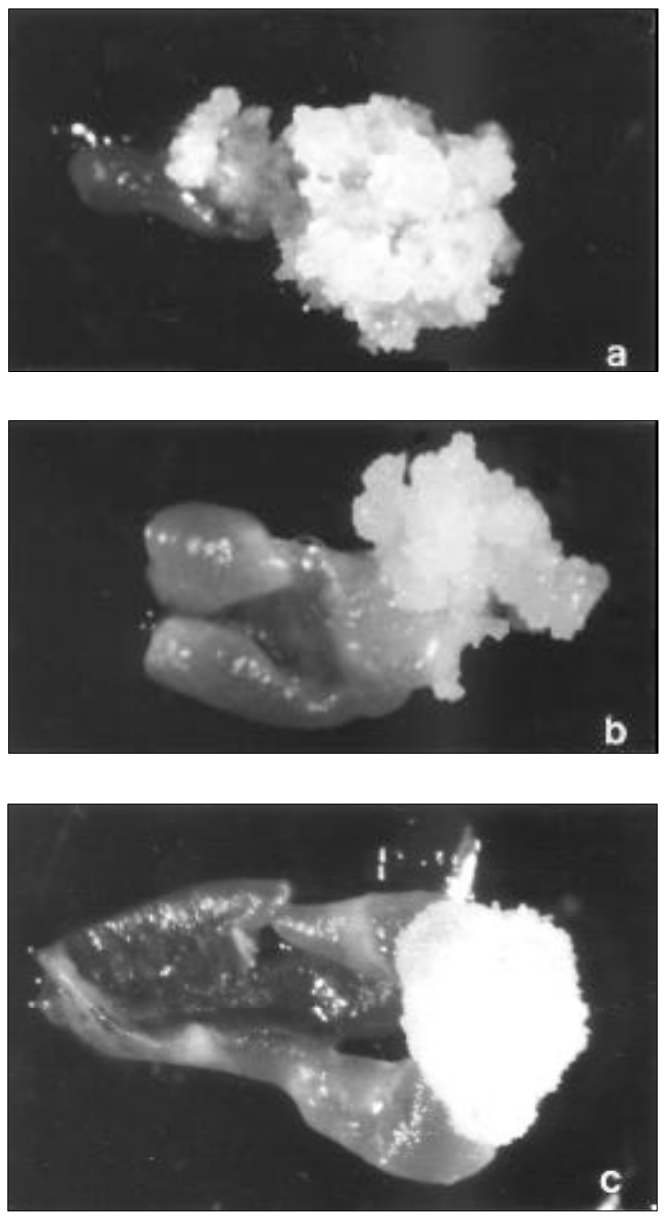

Figure 1 - A. Fast-growing, soft callus. B Slowgrowing, soft callus. C. Slow-growing, hard callus. on all media tested. 'Ponkan' mandarin produced slow-growing, friable calli on all media tested and also hard calli on EBA medium. The different source of nitrogen in 1/2-EME (Grosser \& Gmitter Jr., $1990)$ or the addition of growth regulators on modified EME (EBA) may have positively influenced these results.

The addition of activated charcoal (500 $\mathrm{mg} \mathrm{l}^{-1}$ ) seemed to enhance callus vigor and color for a few varieties, such as 'Natal', that had shown oxidation and slow growth. After two subcultures, better growth and friability were observed on these selections. Mourão Filho \& Grosser (1992) also demonstrated the positive effect of activated charcoal on callus performance, quality and vigor in different species of the Rutaceae family.

In regard to quantitative evaluations, a logistic model with overdispersion was fitted to the proportions of nucelli response to fast- and slowgrowing soft calli (combined), for five Citrus cultivars, i.e., for only those that did not present all counting numbers equal zero. It was considered that the number of soft friable calli have a binomial distribution with the index equal to the number of cultivated nucelli. The analysis of deviance shows that there was a significant interaction between cultivars and media composition (TABLE 1). EME and 1/2-EME media proved best for 'Cravo' mandarin, 'Ponkan' mandarin and 'Serra d'água sweet orange, whereas EBA was the best media composition for soft friable calli induction for 'Murcott' tangor and 'Valencia' sweet orange (Figure 2). There was no soft friable calli induction from 'Pera' and 'Natal' sweet oranges .

Effects of cultivar and media composition on Citrus callus induction, vigor and quality were previously reported. MT medium supplemented with malt extract also induced embryogenic calli of 'Shamouti' sweet orange (Citrus sinensis) but failed to do so with 'Valencia' sweet orange and 'Marsh grapefruit (Citrus paradisi) (Kochba et al., 1972). Mourão Filho \& Grosser (1992) reported the results of non-embryogenic callus induction, friability and vigor of 30 selection of Citrus and its wild relatives from the Rutaceae family. Soft friable callus was obtained from several species, including Aegle marmelos (L.), Afraegle gabonensis (Swing.) Engl., Afraegle paniculata (Schum.) Engl., Balsamocitrus daweii Stapf., Citropsis gilletiana Swing. \& M. Kell., Citrus jambhiri Lush. (rough lemon). Oliveira et al. (1994) also demonstrated the influence of genotype and media composition on embryogenic callus induction. MT supplemented 
TABLE 1 - Analysis of deviance for embryogenic callus induction of seven different Citrus cultivars on three induction media, 120 days after cultured.

\begin{tabular}{lccc}
\hline C.V. & D.F. & Deviance & F \\
\hline Cultivar|Culture media $^{1}$ & 4 & 74.17 & $17.4^{* *}$ \\
Culture media|Cultivar $^{2}$ & 2 & 0.25 & 0.12 n.s. \\
Cultivar.Culture media $^{3}$ & 8 & 31.91 & $3.75^{* *}$ \\
Error & 56 & 59.59 & \\
\hline
\end{tabular}

${ }^{1}$ Cultivar adjusted to culture media; ${ }^{2}$ Culture media adjusted to cultivar; ${ }^{3}$ Interaction cultivar culture media

with indole-acetic acid (IAA) and kinetin induced best nucella response for embryogenic calli formation in 'Cleopatra' mandarin (Citrus reticulata, Blanco) and 'Rangpur' lime (Citrus limonia, L. Osbeck). No callus induction was achieved with Poncirus trifoliata on any of the media tested (MT + malt extract, MT + IAA + kinetin, MT + BA).

Protoplasts were obtained from callus cultures of 5 of 7 cultivars tested (TABLE 2). However, high yields were obtained only from 'Cravo' mandarin, 'Murcott' tangor and 'Ponkan' mandarin.

Suspension cultures were initiated from the different callus lines. After three to four subcultures, suspension cultures of 'Valencia' sweet orange and 'Serra d'água' sweet orange produced a high number of embryos, proving their embryogenic capacity. Mourão Filho \& Grosser (1992) have also demonstrated protoplast isolation soon after callus induction. The best results were always obtained from soft, friable calli.

\section{CONCLUSIONS}

The responses of the seven Citrus varieties on the three callus induction media were variable. 'Cravo' mandarin and 'Murcott' tangor showed the best results, producing friable fastgrowing calli, 120 days after the initiation of the experiment. The other varieties, except 'Pera' sweet orange, also produced friable calli after several subcultures on culture media without any plant growth regulators. These selections can now be used for protoplast isolation and fusion for Citrus somatic hybridization.

\section{ACKNOWLEDGMENT}

This work was supported by Fundação de Amparo à Pesquisa do Estado de São Paulo (FAPESP).

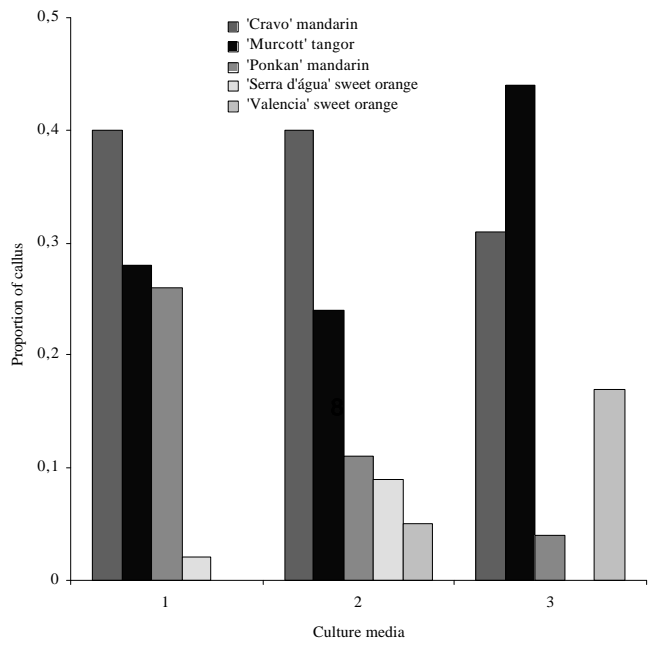

Figure 2 - Proportions of nucellar tissue response in friable callus induction (fast- and slow-growing) of five Citrus cultivars onto three culture media, 120 days after cultured. Culture media 1 = EME; Culture media $2=1 / 2-E M E ;$ Culture media $3=$ EBA.

TABLE 2 - Protoplast yield from embryogenic callus cultures of five selected varieties.

\begin{tabular}{lc}
\hline Variety & Yield $^{1}$ \\
\hline 'Cravo' mandarin & $8.3 \times 10^{5} \pm 1.3$ \\
'Murcott' tangor & $9.6 \times 10^{5} \pm 3.3$ \\
'Ponkan' mandarin & $9.2 \times 10^{5} \pm 4.0$ \\
'Serra d'água' sweet orange & $1.1 \times 10^{4} \pm 0.7$ \\
'Valencia' sweet orange & $1.2 \times 10^{4} \pm 0.9$ \\
\hline
\end{tabular}

1 Yield $=$ number of protoplasrs $/ 500 \mathrm{mg}$ of friable callus. Values represent mean \pm SD of six replicates. 


\section{REFERENCES}

FAO http://apps.fao.org 1998.

GMITTER JR., F.G.; GROSSER, J.W.; MOORE, G.A. Citrus. In: HAMMERSCHLAG, F.A.; LITZ, R.E. (Ed.) Biotechnology of perennial fruit crops. Wallingford: CAB International, 1992, p.335-310.

GROSSER, J.W.; GMITTER JR., F.G. Protoplast fusion and citrus improvement. Plant Breeding Reviews, v.8, p.339-374, 1990.

GROSSER, J.W.; MOURÃO FILHO, F.A.A.; GMITTER JR., F.G.; LOUZADA, E.S.; JIANG, J.; BAERGEN, K.; QUIROS, A.; CABASSON, C.; SCHELL, J.L.; CHANDLER, J.L. Allotetraploid hybrids between citrus and seven related genera produced by somatic hybridization. Theoretical Applied Genetics, v.92, p.577-582, 1996.

KOCHBA, J.; SPIEGEL-ROY, P.; SAFRAN, H. Adventive plants from ovules and nucelli in Citrus. Planta, v.106, p.237-245, 1972.

MOURÃO FILHO, F.A.A.; GROSSER, J.W. Callus induction from Citrus relatives: an alternative source of protoplasts for somatic hybridization experiments. Proceedings of the Florida State Horticultural Society, v.105, p.52-56, 1992.
MOURÃO FILHO, F.A.A.; GROSSER, J.W.; GMITER JR , FG .New tetraploid breeding parents for triploid seedless citrus cultivar development. Fruit Varieties Journal, v.50, n.2, p.76-80, 1996.

MURASHIGE, T.; TUCKER, D.P.H. Growth factor requirements of Citrus tissue culture. Proceedings of the First International Citrus Symposium, v.3, p.1155-1161, 1969.

OLIVEIRA, R.P.; MENDES, B.M.J.; TULMANN NETO, A. Obtenção e cultura de calos nucelares de limão Cravo, tangerina Cleopatra e Poncirus trifoliata. Revista Brasileira de Fisiologia Vegetal, v.6, n.2, p.115-119, 1994.

SAUNT, J. Citrus varieties of the world. Norwich: Sinclair International, 1990. 127p.

Received December 04, 1998

Accepted August 11, 1999 